\title{
The Effects of COVID-19 on Unemployment Insurance Claims
}

\author{
Aaron Amburgey, Research Associate \\ Serdar Birinci, Economist
}

$\mathrm{n}$ early January, Chinese authorities identified the novel virus COVID-19, informally known as coronavirus. Less than three months later, economies across the world are feeling the effects of nationwide lockdowns and economic uncertainty as a result of the coronavirus pandemic. One by one, U.S. cities are imposing the shutdown of public places and non-essential stores, with numerous stores temporarily closing of their own accord. These shutdowns have resulted in a massive, nationwide spike in layoffs.

The increase in layoffs has translated into a dramatic rise in unemployment insurance (UI) claims. On March 21, the number of weekly U.S. UI claims reached nearly 3.3 million-its highest level ever. Layoffs are expected to continue as the economic effects of the pandemic worsen, with the number of people on UI expected to continue to dramatically increase in the coming weeks.

While businesses in many sectors are experiencing losses, earlier negative effects of the coronavirus pandemic have especially affected the service sector. The nature of businesses in this sector-which includes restaurants, entertainment, and transportation services-requires close contact with coworkers or customers, and thus workers in this sector bear the greatest risk of spreading the coronavirus. Because of this, businesses in the service sector have been the first to shut down and workers in this sector have been more likely to experience layoffs early in the crisis.

In the rest of this essay, we analyze the rise in UI claims due to layoffs in the service sector. A simple way of exam-

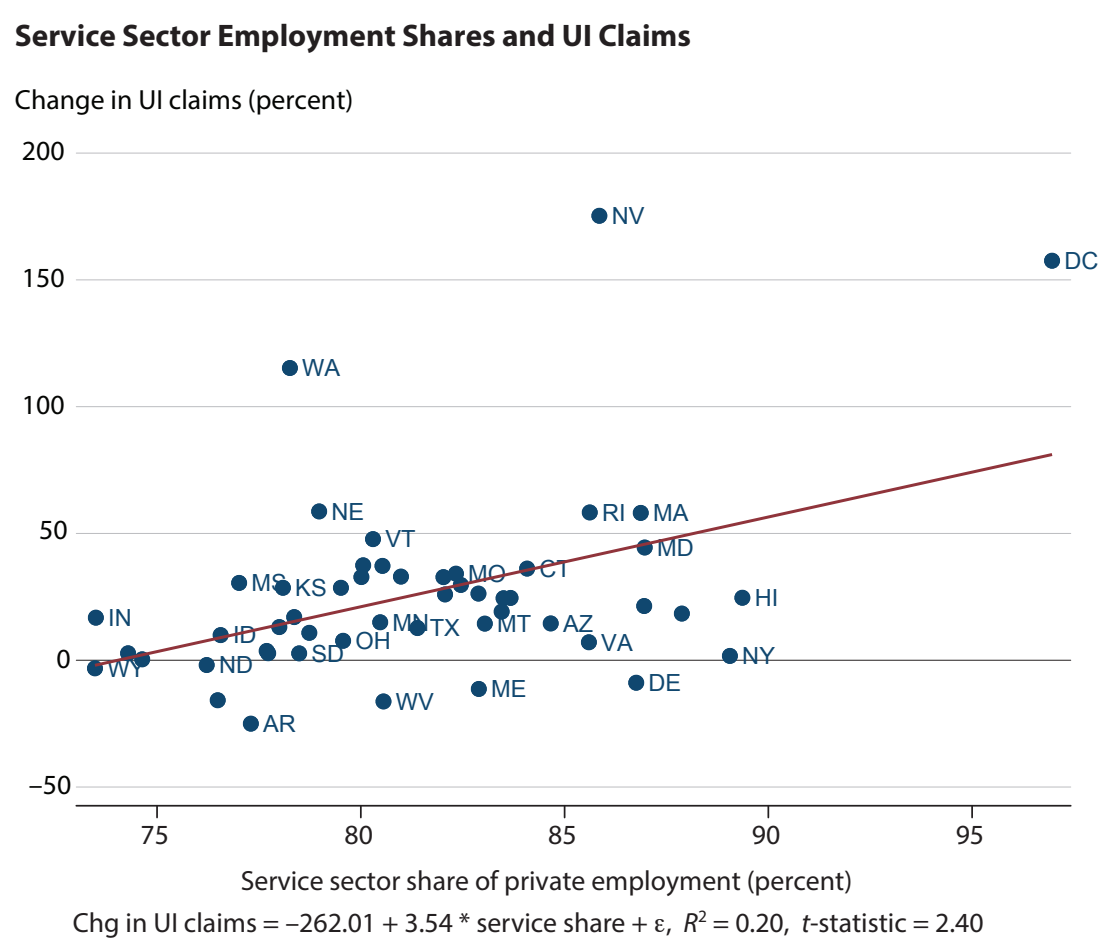

SOURCE: Bureau of Labor Statistics, U.S. Department of Labor. Private sector employment data are from the Bureau of Labor Statistics Quarterly Census of Employment and Wages. Unemployment insurance claims data are from the U.S. Department of Labor Unemployment Insurance Weekly Claims Report. 


\section{ECONOMIC Synopses}

ining this issue is to compare the change in initial claims from March 7 to March 14 between states with varying levels of service sector employment prior to the coronavirus pandemic. In the figure, we show that states with a relatively large share of service sector employment experienced larger increases in UI claims in the week of March 14. In particular, it indicates that an additional 1 percent share of the service sector was associated with around a 3.5 percent increase in UI claims.

\section{The increase in unemployment insurance claims appears to be higher for states with relatively more employees in the service sector.}

States such as Maryland, Nevada, and Massachusetts, which each have a large service share of employment, exhibited large increases in UI claims. Furthermore, states with a particularly low service share of employment, such as Wyoming, Indiana, and Idaho, tend to have low or even negative changes to UI claims. Of course, there are exceptions. Washington, for example, has a low service sector share of employment relative to other states but displayed a large increase in UI claims. On the other hand, Delaware has a relatively high service sector share of employment but experienced a decrease in UI claims.
We find that U.S. states that had a relatively higher service share of employment prior to the crisis were more likely to exhibit dramatic increases in UI claims, which could have important implications for fiscal policies at the state and federal level. For example, we could see that states with higher service sector shares of employment may choose to implement larger fiscal transfers than other states during this crisis.

However, it must be noted that this result does not necessarily prove a causal relationship. For example, it might be the case that in states with large service sectors, governments acted more quickly to prevent the spread of the coronavirus, resulting in all types of businesses shutting down earlier. Alternatively, it might be the case that the coronavirus has spread more quickly in states with larger service sectors and shutdowns occurred earlier as a result. 